\title{
Model forensik literasi dalam pembelajaran daring di masa pandemi: Efektivitas pembelajaran dan responnya
}

\author{
Abdul Rasid Saraha *, Sudir Umar, Nurfatimah Sugrah \\ Universitas Khairun. Jl. Bandara Babullah, Akehuda, Ternate Utara, Kota Ternate, 97728, Indonesia \\ *Corresponding Author. Email: rasidsaraha16@gmail.com
}

Received: 29 August 2020; Revised: 21 January 2021; Accepted: 10 March 2021

\begin{abstract}
Abstrak: Telah dilakukan penelitian penerapan pembelajaran daring (dalam jaringan) menggunakan model forensik literasi (FL), pada materi kinetika reaksi mata kuliah kimia dasar. Tujuan penelitian ini adalah untuk mengetahui efektifitas dan respon mahasiswa dalam pembelajaran ini. Desain dalam penelitian ini adalah pretest dan postest one group design, dengan sampel berjumlah 31 mahasiswa dari program studi pendidikan kimia, FKIP, Universitas Khairun, Ternate. Metode untuk mengetahui efektivitas pembelajaran daring dengan FL menggunakan teknik analisis data paired sample t-test. Keaktifan mahasiswa, ketelusuran literatur dan relevansi argumentasi mahasiswa dalam pembelajaran ini dianalisis dengan metode observasi. Sedangkan respon mahasiswa terkait ketersediaan sumber daya, proses pembelajaran, motivasi belajar, aktivitas literasi, dan pendapat mahasiswa dianalisis dengan menggunakan angket. Berdasarkan analisis data hasil belajar manunjukkan adanya pengaruh antara pembelajaran daring menggunakan model FL dengan hasil belajar mahasiswa. Tanggapan mahasiswa terkait proses pembelajaran juga menunjukkan respon positif, serta mampu meningkatkan motivasi belajar mahasiswa khususnya dalam melakukan aktifitas literasi. Aktivitas literasi mahasiswa dalam pembelajaran ini juga menunjukkan tren positif dengan indikasi tingginya persentase keaktifan mahasiswa dalam mengemukakan argumentasi.
\end{abstract}

Kata kunci: Pembelajaran daring, Pembelajaran di masa pandemi, Model pembelajaran daring.

\section{Forensic literacy models in online learning in a pandemic period: Learning effectiveness and its response}

\begin{abstract}
Research on the Implementation of online learning using the forensic literacy $(F L)$ model has been carried out on the reaction kinetics material of basic chemistry courses. The purpose of this study was to determine the effectiveness and response of students. This study was designed in a one-group pretest and posttest, with a sample of 31 students from the chemistry education study program, FKIP, Khairun University, Ternate. The method to determine the effectiveness of online learning with FL used the data analysis technique paired sample t-test. Student activity, literature traceability, and the student of the relevance of argumentation in this study were analyzed using the observation method. Meanwhile, student responses related to resource availability, learning process, learning motivation, literacy activities, and student opinions were analyzed using a questionnaire. The analysis of learning outcomes data shows that there was an influence between online learning using the FL model and student learning outcomes. Student responses related to the learning process also showed a positive response and were able to increase student motivation, especially in literacy activities. Student literacy activities in this study also showed a positive trend with an indication of the high percentage of student activity in arguing.
\end{abstract}

Keywords: Online learning, Learning in the pandemic, Online learning models.

How to Cite: Saraha, A., Umar, S., \& Sugrah, N. (2021). Model forensik literasi dalam pembelajaran daring di masa pandemi: Efektivitas pembelajaran dan responnya. Jurnal Inovasi Pendidikan IPA, 7(1), 22-33. doi:https://doi.org/10.21831/jipi.v7i1.34149

\section{PENDAHULUAN}

Pandemi akibat penyebaran virus corona (SARS-COV-2), telah menjadi pukulan berat yang berdampak pada berbagai aspek. Akibatnya terjadi perubahan tatanan sosial hingga pada pola pembelajaran dalam pendidikan formal. Protokol kesehatan dengan mewajibkan masyarakat untuk melakukan jaga jarak sosial (social distancing) dan jaga jarak fisik (Physical distancing) menjadi tantangan tersendiri 


\section{Jurnal Inovasi Pendidikan IPA, 7 (1), 2021 - 23}

Abdul Rasid Saraha, Sudir Umar, Nurfatimah Sugrah

dalam penerapan pembelajaran formal baik di Sekolah hingga bangku kuliah (Syah, 2020). Pembelajaran formal di berbagai jenjang pendidikan di Indonesia hingga saat ini masih bertumpu pada pembelajaran dengan metode tatap muka. Saat ini dengan adanya penerapan protokol kesehatan yang ada, menjadikan kegiatan ini tidak dapat dilaksanakan hampir diseluruh wilayah di Indonesia. Hal ini menjadi tantangan bersama sebagai pemangku kepentingan dalam bidang pendidikan. Secara responsif dan taktis, skema pembelajaran daring menjadi tren pembelajaran di era pandemi saat ini. Meskipun berbagai kajian dan prosedur operasional pembelajaran di Sekolah maupun Kampus telah disiapkan dengan tetap menjalankan protokol kesehatan yang ada. Namun pembelajaran daring masih menjadi pilihan yang banyak digunakan dalam mengatasi keterbatasan tatap muka di kelas pada masa saat ini (Syah, 2020).

Pembelajaran daring telah banyak dikembangkan seiring perkembangan teknologi informasi yang sangat dinamis bahkan sebelum massa pandemi. Dalam pembelajaran daring, interaksi guru dan peserta didik dapat dilakukan dari jarak jauh di luar kelas dengan bantuan perangkat teknologi sebagai penghubung/mediator (Setiawan et al., 2019). Kecepatan akses sumber informasi serta keterhubungan lintas ruang dan waktu, menjadikan pembelajaran ini menjadi pilihan dalam meniadakan batas-batas dalam pembelajaran. Hampir semua disiplin ilmu hingga berbagai jenjang pendidikan dapat menggunakan skema pembelajaran daring ini. Bahkan pembelajaran daring juga telah banyak dikembangkan untuk pembelajaran rumpun sain hingga kimia yang banyak menyajikan eksperimen laboratorium dalam pembelajarannya (Aliyu \& Talib, 2019; Tatli \& Ayas, 2010, 2013). Banyaknya literatur dalam bentuk referensi artikel, maupun video yang dapat diakses dengan memasukkan kata kunci yang tepat dalam mesin pencarian digital, membuat pembelajaran daring memungkinkan terjadi multi-interaksi antara guru dengan pelajar maupun dengan sumber pustaka yang tersedia bebas (Cheung \& Cable, 2017). Kata kunci (keyword) menjadi bagian penting dalam membuka jalur literasi pada pembelajaran daring. Dengan menggunakan kata kunci, difinisi hingga diskripsi dapat ditemukan secara cepat sehingga mampu mempersingkat waktu penelusuran pustaka jika dibandingkan dengan metode penelusuran konvensional. Dengan menggunakan metode pembelajaran daring, hasil penelitian telah menunjukkan hasil yang positif dengan peningkatan hasil belajar (Badriyah et al., 2020). Laporan ini merupakan potensi yang dapat menjadi bahan kajian untuk memperluas dimensi pengembangan pembelajaran daring ke depan.

Meskipun pembelajaran daring telah banyak dilaporkan dapat meningkatkan hasil belajar, namun sejumlah keterbatasan dalam pembelajaran daring perlu menjadi perhatian. Secara umum, pembelajaran daring di Indonesia banyak terkendala pada ketersediaan jaringan untuk dapat diakses oleh komponen pembelajar. Hingga saat ini, tahun 2020 masyarakat yang dapat mengakses internet di Indonesia dilaporkan oleh laman wearesocial.com masih sekitar 175,4 juta atau sebesar $64 \%$ dari populasi 272,1 juta jiwa. Disamping dipengaruhi oleh sumber daya pendukung, model pembelajaran daring juga dapat berpengaruh terhadap proses dan hasil belajar (Badriyah et al., 2020). Model pembelajaran seperti inquiri yang banyak digunakan dalam pembelajaran tatap muka, juga dilaporkan penggunaannya dalam pembelajaran daring (Chanprasitchai \& Khlaisang, 2016). Hal ini menunjukkan bahwa model pembelajaran berperan penting dalam kelancaran dan keberhasilan pebelajaran daring. Model pembelajaran memberikan gambaran jelas terhadap proses pembelajaran yang dilaksanakan, dimana didalamnya memuat langkah ataupun tahapan hingga durasi pembelajan yang direncanakan. Dalam pembelajaran daring, penerapan model pembelajaran penting dilakukan untuk mendapatkan pembelajaran yang menarik sehingga memberikan pengalaman serta mendapatkan capaian pembelajaran yang direncanakan (Picciano, 2017).

Dalam penelitian sebelumnya, kami telah mengembangkan model forensik literasi (FL) untuk pembelajaran daring. Pengembangan model menggunakan metode 4D, dengan menghasilkan 6 langkah/ tahap pembelajaran. Hasil pengembangan dinyatakan dalam kriteria sangat valid dengan nilai 3,33 dari skala 4. Sedangkan hasil uji coba terbatas pembelajaran daring, menunjukkan keaktifan pelajar dalam pembelajaran ini sebesar 87,5\% dengan kategori sangat aktif (Rakhman et al., 2018). Setelah melalui tahap pengembangan, sangat penting model pembelajaran diuji efektifitas dan respon penerapannya agar memberikan informasi yang utuh sebelum digunakan secara luas. Efektifitas dan respon penerapan model pembelajaran merupakan hal penting yang dapat dijadikan dasar evaluasi maupun pengembangan pada tahap selanjutnya. Untuk mendapatkan efektifitas dan respon penggunaan model ini dalam pembelajaran, dalam artikel ini akan disajikan laporan hasil penerapan model FL pada pembelajaran daring. 


\section{Jurnal Inovasi Pendidikan IPA, 7 (1), 2021 - 24}

Abdul Rasid Saraha, Sudir Umar, Nurfatimah Sugrah

Peningkatan hasil belajar dan respon terhadap penerapan model FL menjadi fokus pembahasan dalam artikel ini.

\section{METODE}

Penelitian yang telah dilakukan merupakan eksperimen semu yang bertujuan mengetahui pengaruh penggunaan pembelajaran daring dengan menggunakan model forensik literasi terhadap hasil belajar mahasiswa program studi pendidikan kimia FKIP Unkhair dalam mempelajari kinetika reaksi. Desain dalam penelitian ini adalah pretest dan postest one group design dengan menggunakan satu kelas eksperimen. Sedangkan dalam mendapatkan respon mahasiswa, digunakan teknik angket dengan google form yang disebarluaskan secara daring. Validasi instrumentasi angket dilakukan dengan metode validasi ahli. Angket respon siswa terdiri dari 4 indikator, diantaranya ketersediaan sumber daya, proses pembelajaran, angket pengukuran motivasi, aktivitas literasi, dan pendapat mahasiswa terhadap pelaksanaan pembelajaran daring. Sampel dalam penelitian yang telah dilakukan sebanyak 31 dari total populasi sebanyak 65 mahasiswa semester 2, dengan pengambilan sampel menggunakan teknik random sampling. Analisis data hasil belajar mahasiswa dalam pembelajaran daring menggunakan model FL pada materi kinetika kimia menggunakan teknik analisis data paired sample t-test. Teknik analisis data ini untuk menguji hasil belajar pretest dan posttest mahasiswa.

Tahap pembelajaran daring menggunakan model FL dilaksanakan pada aplikasi google class, dan dilaksanakan sesuai sintak model yang terdiri dari 6 langkah pembelajaran (Tabel 1). Pembelajaran diawali dengan pendahuluan yang di dalamnya terdapat uraian masalah atau fenomena awal yang menjadi topik bahasan. Tahapan yang kedua adalah membagikan kata kunci untuk ditelusuri dan dipelajari oleh mahasiswa. Tindak lanjut hasil penelusuran, para mahasiswa diberikan waktu untuk menuliskan hasil belajar/ diskusi dan literasinya dalam beberapa waktu. Tahapan yang ketiga adalah proses pengulasan dari uraian atapun jawaban dari para mahasiswa sekaligus melakukan penelusuran orisinalitas jawaban dari mahasiswa. Langkah yang keempat adalah tahap diskusi. Dalam tahap ini, diberikan pertanyaan tambahan terkait hasil penelusuran mahasiswa, yang kemudian memberikan waktu kembali kepada mahasiswa agar melakukan penelusuran pustaka serta berdiskusi dengan teman untuk menjawab pertanyaan tambahan tersebut. Pada proses diskusi, pengajuan pertanyaan tambahan dilakukan secara berulang untuk memastikan bahasan pembelajaran memenuhi capaian pembelajaran yang direncanakan. Selanjutnya langkah yang kelima adalah membangun kesimpulan. Mahasiswa diberikan kesempatan terlebih dahulu untuk mengusulkan kesimpulan pembelajaran, dalam tahap pembangunan kesimpulan. Langkah yang terakhir adalah penutup, pada langkah ini berbagai usulan kesimpulan yang di kemukakan dikoreksi, dipilih dan dikemukakan kembali sesuai target pembelajaran pada topik bahasan yang dipelajari. Selanjutnya memberikan apresiasi kepada semua peserta dan pernyataan penutup (Rakhman et al., 2018). Dalam proses pembelajaran menggunakan model FL, observasi dilakukan untuk melihat tingkat keaktifan mahasiswa, persentase ketelusuran pustaka dan orisinalitas jawaban ataupun pernyataan dalam diskusi (Tabel 2). Tingkat keaktifan siswa diukur berdasarkan persentase mahasiswa yang mengikuti pembelajaran daring. Ketelusuran pustaka dianalisis dengan menelusuri jawaban/pernyataan mahasiswa yang dituliskan dalam kolom komentar pada mesin pencarian. Sedangkan orisinalitas diukur berdasarkan persentase jumlah jawaban/argumentasi yang bukan merupakan hasil copy/paste dari literatur/pustaka yang tertelusur.

\section{HASIL DAN PEMBAHASAN}

\section{Karakteristik model forensik literasi}

Model pembelajaran forensik literasi merupakan pembelajaran pasif daring yang dikembangkan dengan 6 tahapan pembelajaran (Tabel 1). Dalam pembelajaran ini, interaksi antara pendidik dan peserta didik dilakukan melalui bantuan aplikasi sejenis chat, dimana komunikasi yang dilakukan dalam bentuk teks. Kelebihan metode pembelajaran pasif daring salah satunya adalah memberikan kesempatan yang lebih banyak kepada peserta untuk mengeksplorasi materi pembelajaran. Metode pembelajaran ini juga memberikan kesempatan bagi semua peserta untuk dapat mengemukakan argumentasi/gagasannya terkait topik yang dipelajari (Yen et al., 2018).

Keaktifan mahasiswa yang merata juga ditunjukkan dalam pembelajaran model forensik literasi ini. Berdasarkan hasil observasi keaktifan mahasiswa dalam pembelajaran ini, tercatat $87.09 \%$ dengan kategori sangat tinggi. Persentase aspek keaktivan mahasiswa dalam penerapan pembelajaran ini tidak 


\section{Jurnal Inovasi Pendidikan IPA, 7 (1), 2021 - 25}

Abdul Rasid Saraha, Sudir Umar, Nurfatimah Sugrah

jauh berbeda dengan hasil ujicoba terbatas. Keaktifan mahasiwa (Tabel 2) dianalisis dari jumlah respon jawaban/komentar terhadap pertanyaan dan ilustrasi masalah yang diberikan. Persentase menunjukkan banyaknya jawaban/argumentasi dari jumlah total mahasiswa yang mengikuti kelas daring tersebut. Angka ini menjadi penting dilaporkan karena menunjukkan partisipasi mahasiswa yang hampir merata dalam pembelajaran daring ini. disamping keaktifan mahasiswa dalam berargumentasi dan menjawab pertanyaan, observasi juga dilakukan pada aktifitas dan kemampuan literasi (ketelusuran pustaka), pemilihan pustaka yang baik/relevan, kualitas hasil literasi seperti relevansi jawaban dengan pertanyaan, serta orisinilitas jawaban mahasiswa.

Tabel 1. Tahapan model FL

\begin{tabular}{|c|c|}
\hline Langkah & Deskripsi \\
\hline $\begin{array}{l}\text { 1. Pengantar/ pendahuluan } \\
\text { (Introduction) }\end{array}$ & $\begin{array}{l}\text { a. Menjelaskan jadwal/ teknis pembelajaran daring. } \\
\text { b. Menyampaikan tujuan dan capaian pembelajaran. } \\
\text { c. Menuliskan deskripsi hasil pengamatan kasus/masalah/penelitian, dll dengan } \\
\text { menyisipkan kata kunci dari masalah tersebut. }\end{array}$ \\
\hline $\begin{array}{l}\text { 2. Membagikan kata kunci } \\
\text { (Sharing the keyword) }\end{array}$ & $\begin{array}{l}\text { a. Menginstruksikan peserta didik untuk melakukan penelusuran baik } \\
\text { digital/manual terkait kata kunci yang diberikan. } \\
\text { b. Memberikan kesempatan kepada peserta didik untuk menyampaikan hasil } \\
\text { penelusuran terkait kata kunci yang telah diberikan. }\end{array}$ \\
\hline 3. Pengulasan (Riview) & $\begin{array}{l}\text { a. Memilah pernyataan/jawaban hasil penelusuran peserta didik yang relevan. } \\
\text { b. Menulusuri orisinalitas pernyataan/jawaban yang relevan pada pokok bahasan. } \\
\text { a. Memberikan apresiasi semua jawaban yang telah diunggah oleh peserta didik. } \\
\text { b. Memilih komentar/jawaban peserta didik terkait pokok bahasan yang relevan } \\
\text { dan orisinil. }\end{array}$ \\
\hline 4. Diskusi (Discussion) & $\begin{array}{l}\text { c. Memberikan pertanyaan tambahan yang lebih mendalam terkait } \\
\text { pertanyaan.jawaban peserta didik yang dinilai relevan dan orisinil. } \\
\text { d. Memberikan kesempatan peserta didik untuk menjawab secara ilmiah (kembali } \\
\text { pada langkah 2c-4b) }\end{array}$ \\
\hline $\begin{array}{l}\text { 5. Pembangunan } \\
\text { kesimpulan (Conclusion }\end{array}$ & $\begin{array}{l}\text { a. Memberikan pertanyaan yang mengarah pada pembangunan kesimpulan. } \\
\text { b. Memberikan kesempatan kepada peserta didik untuk mengusulkan kesimpulan } \\
\text { hasil pembahasan. }\end{array}$ \\
\hline 6. Penutup (enclosed) & $\begin{array}{l}\text { c. Memberikan apresiasi atas usulan kesimpulan dari peserta didik. } \\
\text { a. Memberikan deskripsi masalah yang mencakup kesimpulan dari pokok } \\
\text { bahasan pembelajaran. } \\
\text { b. Memberikan pernyataan penutup. }\end{array}$ \\
\hline
\end{tabular}

Tabel 2. Hasil observasi pembelajaran

\begin{tabular}{cc}
\hline Pengamatan & Persentase (\%) \\
\hline Keaktifan mahasiswa & 87,09 \\
Ketelusuran pustaka & 78,94 \\
Pustaka relevan & 62,38 \\
Jawaban relevan & 62,36 \\
Jawaban orisinil & 60,54 \\
\hline
\end{tabular}

Dalam pembelajaran daring menggunakan model FL, ketelusuran pustaka dianalisis dengan cara melakukan penelusuran kembali terhadap jawaban/pertanyaan mahasiswa dalam pembelajaran daring. Penelusuran sumber pustaka yang digunakan mahasiswa dilakukan melalui aplikasi mesin pencarian maupun referensi cetak yang menjadi sumber pustaka. Berdasarkan hasil analisis ketelusuran pustaka yang digunakan mahasiswa dalam pembelajaran daring, persentase $78,94 \%$ dengan kategori tinggi, mencerminkan bahwa dalam pembelajaran daring, mahasiswa telah mampu memberikan informasi pustaka yang dapat ditelusuri. Ketelusuran pustaka selanjutnya dianalisis lebih lanjut terkait relevansi pustaka yang digunakan. Indikator yang digunakan untuk menentukan pustaka yang relevan diantaranya berupa buku cetak atau buku elektronik, dan artikel dengan pengarang/penulis yang jelas, serta memiliki pustaka rujukan dalam penulisannya. Berdasarkan indikator ini, pustaka relevan yang digunakan mahasiswa dalam pembelajaran daring sebesar $62,38 \%$ dengan kategori tinggi.

Observasi lebih lanjut dilakukan terhadap jawaban/argumentasi mahasiswa yang telah melakukan kajian puastaka dalam merespon pertanyaan/ilustrasi masalah yang diangkat pada pembelajaran ini. Hasil observasi menunjukkan jawaban relevan dari mahasiswa dalam pembelajaran menggunakan 
model ini sebesar 62,36\% dengan kategori tinggi. Analisis jawaban relevan dilakukan pada setiap jawaban/argumentasi mahasiswa dalam pembelajaran daring, yang didasarkan terhadap kesesuaian, ketepatan dan keakuratannya dengan soal/ilustrasi masalah yang diangkat dalam pembelajaran ini. Dalam analisis jawaban relevan mahasiswa, penilian tidak terbatas pada jawaban benar atau salah, sehingga bukan merupakan unsur penilaian kuantitatif. Hal ini merupakan aspek pembeda dengan analisis hasil belajar mahasiswa yang mengandung unsur penilaian kuantitaif dalam penerapannya.

Kegiatan observasi penelusuran pustaka, studi pustaka hingga menyajikan hasil studi pustaka dalam bentuk argumen yang merupakan aktifitas literasi mahasiswa dalam pembelajaran ini. Aktifitas ini merupakan representasi dari keterampilan literasi mahasiswa dengan indikator, kemampuan mencari sumber pustaka, memahami literatur, mengelola informasi dan menyajikan informasi. Literasi merupakan proses mendapat dan mengelola informasi menjadi suatu pengetahuan tanpa plagiarisme di dalamnya (Abidin \& Jupri, 2017). Literasi informasi merupakan kemampuan individu dalam mengenali kapan informasi dibutuhkan, dan memiliki kemampuan untuk menemukan, mengevaluasi dan menggunakan kebutuhan informasi tersebut. Ada 7 langkah dalam ketrampilan literasi informasi yaitu: merumuskan masalah, mengidentifikasi sumber informasi, mengakses informasi, menggunakan informasi, menciptakan karya, mengevaluasi dan menarik pelajaran (Mirazita \& Rohmiyati, 2015). Keterampilan literasi dalam pembelajaran daring menggunakan model FL, sangat diperlukan untuk mengembangkan pembelajaran yang aktif.

Model FL dikembangkan dengan memodifikasi sembilan rangkaian kerja dalam proses pembuktian ilmu forensik (Meiyanti \& Ismaniah, 2015); (1) Identification: mengenal dan mengamati suatu perkara serta menentukan jenis perkaranya. (2) Preparation: melibatkan teknik, mencari barang bukti, memonitor serta mengelolanya. (3) Approach strategy: memformulasikan prosedur dan pendekatan yang digunakan untuk memaksimalisasikan pengumpulan bukti-bukti dan meminimalisasi pengaruhnya terhadap korban. (4) Preservation: pengamanan, penjagaan dan pengasingan terhadap bukti secara materil dan digital. (5) Collection: mencatat dan mengumpulkan bukti-bukti sesuai standar dan prosedur yang diterima. (6) Examination: memeriksa pencarian yang sistematik dari bukti-bukti yang berhubungan dengan tersangka criminal. (7) Analysis: menganalisis hasil dari bukti-bukti yang diperiksa. (8) Presentation: mengambil kesimpulan dari apa yang telah dirangkum dan dijelaskan. (9) Returning Evidence: mengembalikan kepada pemiliknya baik bukti-bukti berupa material dan digital. Secara sederhana, aktifitas dalam pembelajaran daring menggunakan model FL dapat digambarkan seperti pada Gambar 1. Model forensik literasi didesain dengan cara mengadopsi tahapan forensik yang kemudian dikolabirasikan dengan pembelajaran literasi, ini digambarkan sebagai upaya pencarian pengetahuan berdasarkan capaian pembelajaran oleh mahasiswa, dengan melakukan penelusuran literasi dari kata kunci pokok bahasan pembelajaran yang diunggah pada dinding aplikasi pembelajaran elektronik (daring) oleh guru/dosen. Kunci dari model pembelajaran ini diantaranya: kata kunci (keyword) yang diasumsikan dengan suatu temuan kasus/masalah yang perlu dianalisis lebih lanjut, penelusuran literatur (literacy) yang diasumsikan sebagai metode analisis hingga proses pengumpulan bukti-bukti yang terkait dengan kata kunci yang disajikan, serta penarikan kesimpulan menggunakan keterampilan berpikir kritis (Rakhman et al., 2018).

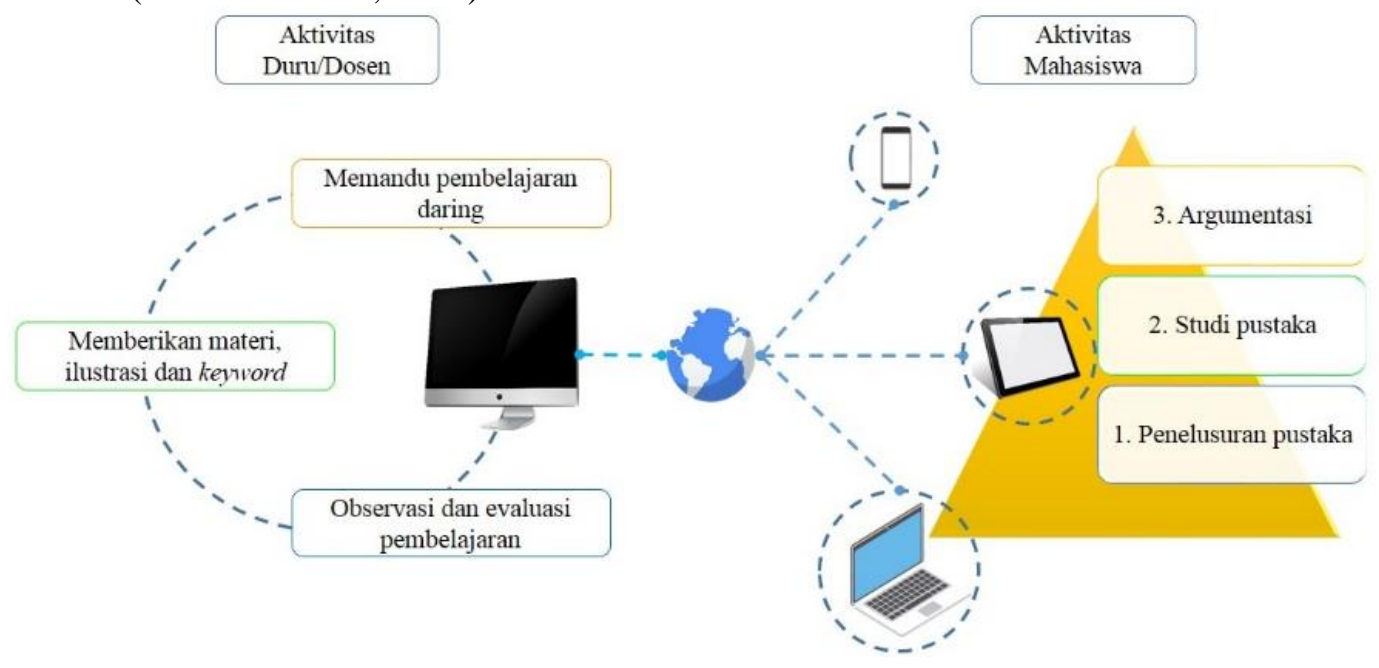

Gambar 1. Ilustrasi pembelajaran FL 


\section{Jurnal Inovasi Pendidikan IPA, 7 (1), 2021 - 27}

Abdul Rasid Saraha, Sudir Umar, Nurfatimah Sugrah

Pembelajaran daring menggunakan model FL memiliki keunggulan diantaranya, mendorong keaktifan dalam melakukan studi pustaka secara mandiri, memperbanyak peran mahasiswa dalam diskusi, serta memberikan kesempatan mahasiswa melakukan literasi pada saat pembelajaran berjalan. Keaktifan pembelajaran FL yang terjadi antara guru/dosen dengan mahasiswa sangat dipengaruhi oleh ilustrasi masalah dan kata kunci yang diberikan kepada mahasiswa.

\section{Efektivitas pembelajaran}

Hasil belajar mahasiswa dalam materi kinetika reaksi dianalisis menggunakan teknik analisis data paired sample t-test. Tahap awal analisis dimulai dengan uji prasarat normalitas dengan Kolmogorov-Smirnov ${ }^{\text {a }}$ (Tabel 3). Berdasarkan Tabel 3, Nilai signifikansi pretest $0,092 \geq 0,05$, sehingga data terdistribusi normal, dan nilai signifikasi posttest $0,050 \geq 0,05$, sehingga data terdistribusi normal. Sedangkan nilai signifikasi analisis paired sample menunjukkan $0,000 \leq 0,005$, sehingga ada perbedaan rata-rata nilai pretest dan posttest. Dengan kata lain, terdapat pengaruh model pembelajaran forensik literasi terhadap hasil belajar mahasiswa.

Tabel 3. Uji normalitas

\begin{tabular}{cccc}
\hline & Statistik & df & Sig. \\
\hline Pretest & .146 & 31 & .092 \\
Postest & .157 & 31 & .050 \\
\hline
\end{tabular}

Pembelajaran daring menekankan kepada mahasiswa untuk memperoleh informasi dan mengelolahnya dalam bentuk online. Menurut Moore et al. (2011) pembelajaran daring adalah akses ke pengalaman belajar melalui penggunaan beberapa teknologi. Selain itu Moore et al. (2011) juga berpendapat bahwa daring adalah versi pembelajaran jarak jauh yang lebih baru yang meningkatkan akses kesempatan pendidikan bagi peserta didik yang digambarkan sebagai non-tradisional. Pembelajaran daring menumbuhkan pedagogik yang berbeda dan seperangkat keterampilan yang unik dari kelas tradisional (Boling et al., 2012). Daring membuat pembelajaran lebih efeisien dan menarik, dengan pembelajaran daring mahasiswa bisa mengakses pembelajaran secara teratur dan menemukan informasi yang diperlukan melalui portal daring, dan daring menawarkan lebih banyak kebebasan bagi mahasiswa (Gorbunovs et al., 2016).

Penelitian Lee et al. (2011) menunjukkan bahwa ada korelasi yang signifikan antara dukungan kesiapan siswa dalam pembelajaran daring, sehingga juga berpengaruh terhadap hasil belajar mereka. Hasil penelitian ini juga menunjukkan mahasiswa cenderung lebih puas dengan pembelajaran daring. Sebuah penelitian meta analisis yang dilakukan Zheng et al. (2020) tentang tipe pembelajaran, dari 45 studi yang membandingkan efektivitas pembelajaran tatap muka, pembelajaran daring, dan blended, ditemukan adanya hasil positif dalam pembelajaran daring. Dikemukakan juga bahwa dalam penelitian hasil belajar siswa lebih baik ketika dalam pembelajaran online. Selain itu, hasil penelitian Yen et al. (2018) juga menunjukkan bahwa hasil belajar siswa efektif pada pembelajaran online.

Pembelajaran daring dapat memfasilitasi peserta didik dalam mengambil kendali atas konten, mengolah urutan pembelajaran, menentukan kecepatan dalam pembelajaran, memperbaiki waktu sampai pada memilih media sendiri untuk memenuhi tujuan pembelajaran mereka serta mengolah akses ke metode dan bahan daring (Oludare Jethro et al., 2012). Dalam pembelajaran daring dengan menggunakan metode forensik literasi, mahasiswa dituntut untuk berperan aktif selama proses pembelajaran. Selama proses pembelajaran mahasiswa berperan dalam mencari berbagai informasi dari setiap permasalahan yang diajukan oleh dosen. Informasi-informasi ini atau solusi masalah yang diajukan dosen bisa dicari dengan literasi online. Oleh karena itu, salah satu kelebihan dari pembelajaran online ini adalah mahasiswa bisa langsung melakukan pencarian informasi lewat online. Keaktifan mahasiswa selama proses pembelajaran online mampu meningkatkan hasil belajar mahasiswa.

\section{Respon mahasiswa}

Respon mahasiswa terhadap pembelajaran daring yang telah dilakukan, dianalisis pada aspek ketersediaan sumberdaya, pelaksanaan pembelajaran, motivasi dan proses literasi dalam pembelajaran tersebut. Secara rinci, respon mahasiswa terhadap beberapa aspek tersebut dideskripsikan sebagai berikut. 
Jurnal Inovasi Pendidikan IPA, 7 (1), 2021 - 28

Abdul Rasid Saraha, Sudir Umar, Nurfatimah Sugrah

\section{Ketersediaan sumber daya}

Aspek ketersediaan sumber daya, dianalisis untuk mengetahui kesiapan, dan kesanggupan mahasiswa dalam mengikuti pembelajaran daring ini. Hasil analsis aspek ini disajikan pada diagram ketersediaan sumber daya (Gambar 2). Aspek ketersediaan sumber daya dalam pembelajaran daring ini dilihat dari 2 indikator utama, yakni ketersediaan fasilitas baik internet dan perangkat keras sebagai penunjang keikutsertaan mahasiswa dalam pembelajaran daring. Kedua, kemampuan mahasiswa dalam mengoperasikan atau menggunakan aplikasi untuk mengikuti pembelajaran daring. Ketersediaan fasilitas dari internet, perangkat keras maupun aplikasi google class (GC) adalah wajib disediakan oleh mahasiswa. Sebanyak 30 mahasiswa yang mengembalikan jawaban angket dari 31 mahasiswa sampel, 100\% menjawab memiliki perangkat keras seperti komputer/laptop, smartphone ataupun tablet untuk mengikuti pembelajaran daring. Ini memberikan informasi bahwa alat untuk pembelajaran daring bukalan masalah yang dihadapi mahasiswa sampel. Selain ketersediaan perangkat keras, rata-rata mahasiswa lebih dari $80 \%$ dapat mengakses internet dengan tanpa kendala.

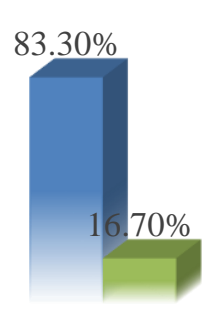

(a)

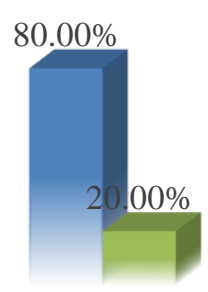

(b)

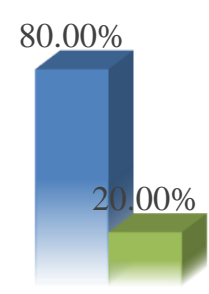

(c)

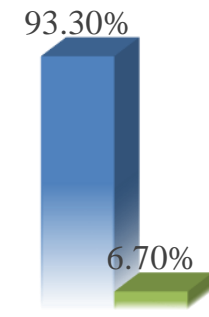

(d)

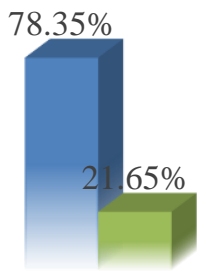

(e)

$$
\% \text { Ya }=\% \text { Tidak }
$$

Gambar 2. Diagram ketersediaan sumber daya.

(a) Kemampuan akses internet, (b) Fasilitas internet pribadi (c)Kemampuan mahasiswa mendapatkan aplikasi GC, (d) Kemampuan mahasiswa mengoperasikan GC, (e) Kemampuan mengikuti pembelajaran daring dengan

GC.

Di sisi lain, kemampuan mahasiswa sebagai komponen sumberdaya manusia dalam mendapatkan dan mengoperasikan aplikasi GC utuk pembelajaran daring juga menunjukkan respon positif dengan persentase yang tinggi berturut-turut $80 \%$ dan $93,3 \%$. Persentase ini menunjukkan bahwa sebagian besar mahasiswa tidak mengalami kesulitan untuk mendapatkan aplikasi GC, yang memang tersedia bebas baik dalam aplikasi web, maupun smartphone. Kendala sedikit berarti dilaporkan pada kemampuan mengikuti pembelajaran daring menggunakan GC, dengan persentase ketidak mampuan sebesar $21,65 \%$. Kesulitan ini teridentifikasi pada aktivitas pengumpulan tugas yang tidak pada tempatnya (halaman tugas). Selain pengumpulan tugas, sebagian mahasiswa juga melaporkan mengalami kesulitan pada aktivitas berkomentar pada sesi diskusi dalam pembelajaran daring. Dugaan kesulitan mahasiswa dalam mengikuti pembelajaran daring dengan aplikasi GC, mengerucut pada pengalaman mahasiswa yang baru pertama menggunakan aplikasi tersebut, tanpa adanya pelatihan ataupun bimbingan teknis penggunaanya sebelumnya. Hal ini sejalan dengan penelitian yang dilakukan oleh (Jeong \& HmeloSilver, 2010), bahwa salah satu tantangan dalam sumber daya pembelajaran online yaitu mahasiswa mungkin mengalami kesulitan dalam mencari, menavigasi, dan menemukan informasi online. Hal ini sebagian disebabkan oleh besarnya informasi, terutama bila pencarian literasi di internet. Literasi dalam internet beragam informasi termasuk sumber daya primer, juga bisa menjadi tantangan karena siswa perlu mencari dan menyaring informasi dalam jumlah besar sebelum mereka dapat menemukan apa yang mereka cari. Selain itu, informasi di internet tidak terorganisir dengan baik atau tidak terkontrol kualitasnya.

\section{Proses pembelajaran daring}

Respon mahasiswa pada aspek proses pembelajaran daring diminta untuk memberikan informasi terkait penyelenggaraan pembelajaran daring menggunakan model FL. Adapun indikator yang dianalisis diantaranya, jadwal pelaksanaan dan alokasi waktu pebelajaran daring, kemudahan akses materi perkuliahan, pengetahuan maupun pemahaman mahasiswa pada instruksi dan pertanyaan dari dosen, serta 


\section{Jurnal Inovasi Pendidikan IPA, 7 (1), 2021 - 29}

Abdul Rasid Saraha, Sudir Umar, Nurfatimah Sugrah

kesempatan mahasiswa untuk aktif dalam pembelajaran daring. Hasil analisis aspek ini disajikan pada diagram proses pembelajaran daring (Gambar 3). Instrumen angket menurunkan beberapa indikator tersebut dalam 9 pertanyaan, dengan pilihan jawaban ya dan tidak.

Kesesuaian jadwal dan alokasi waktu dalam proses pembelajaran daring diturunkan dalam 2 pertanyaan angket terkait jadwal dan durasi waktu pembelajaran daring. Berdasarkan respon mahasiswa, jadwal dan alokasi waktu menunjukkan perbedaan respon yang sama besar. Hal ini menunjukkan bahwa pembelajaran ini memiliki kelebihan terkait fleksibiltas waktu, disisi lain mempunyai kelemahan dalam manajemen waktu pembelajaran. Waktu dan durasi sangat penting dalam menciptakan pembelajaran yang efektif. waktu dan durasi pembelajaran merupakan salah satu faktor yang berpengaruh terhadap efektivitas pembelajaran, karena berhubungan dengan konsentrasi pembelajar. Efektivitas pembelajaran dapat diciptakan pada kondisi dimana baik guru/dosen dengan mahasiswa dalam keadaan siap belajar (Oktavian \& Aldya, 2020).

Dalam proses pembelajaran daring yang dibatasi oleh jarak, membangun komunikasi antara guru/ dosen dengan mahasiswa menjadi tantangan tersendiri. Untuk mengetahui materi dan penjelasan dari guru/dosen dalam pembelajaran daring dapat diterima dengan baik oleh mahasiswa, maka diperlukan respon mahasiswa terkait aksesibilitas materi, kemudahan menemukan instruksi dan pemahaman terhadap ilustrasi/materi yang disajikan. Pada ketiga komponen ini, persentase respon mahasiswa memberikan hasil yang berbeda. Aksesabilitas dan kemudahan menemukan instruksi ataupun materi perkuliahan mendapatkan respon sangat baik dengan persentase keduanya lebih dari 83\%. Hal ini menunjukkan bahwa sebagian besar mahasiswa dapat mengakses dan menemukan instruksi/materi kuliah pada saat pembelajaran daring menggunakan aplikasi GC. Namun persentase pemahaman mahasiswa terhadap materi dan instruksi pada pembelajaran ini mengalami penurunan pada kategori tinggi dengan persentase $76,70 \%$ dibandingkan pengetahuan mahasiswa dalam mendapatkan materi tersebut.

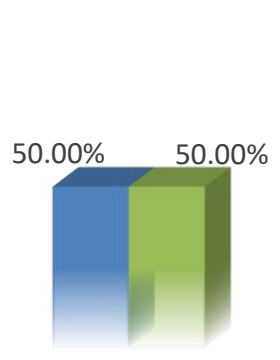

(a)

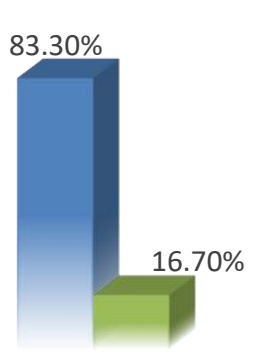

(b)

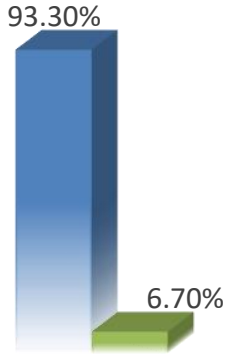

(c)

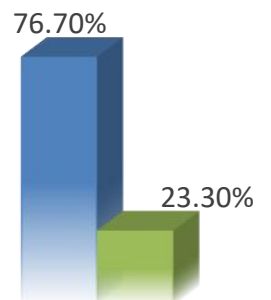

(d)

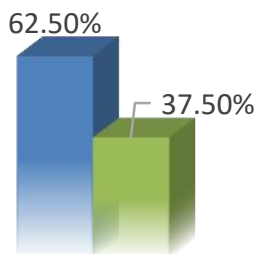

(e)

- $\%$ Ya $\%$ Tidak

Gambar 3. Diagram respon mahasiswa untuk proses pembelajaran daring

Dimana: (a) Kesesuaian jadwal dan alokasi waktu, (b) Kemudahan mendapatkan materi kuliah, (c) Kemudahan mengetahui instruksi dosen, (d) Kemudahan pemahaman ilustrasi dosen, dan (e) Kesempatan mahasiswa untuk aktiv dalam pembelajaran.

Kegiatan pembelajaran daring dengan model FL, membutuhkan keaktifan dan kemandirian belajar mahasiswa dalam memahami materi perkuliahan. Ada sejumlah faktor yang dapat mempengaruhi pembelajaan daring diantaranya, kemampuan mahasiswa dalam menggunakan perangkat komputer/ gawai, pemahaman terhadap teknologi (aplikasi online), kesiapan mahasiswa menerima materi pembelajaran melalui aplikasi online, dan sikap mahasiswa terhadap teknologi informasi (Setiaji \& Dinata, 2020).

Respon terhadap pernyatan mahasiswa diberikan kesempatan untuk aktiv pada saat pembelajaran daring dilaksanakan, menunjukkan bahwa sebagian besar mahasiswa memberikan respon positif dengan persentase $62,50 \%$. Data ini juga dapat dikonfirmasi dengan keaktivan mahasiswa dalam pembelajaran daring (Tabel 2), yang menunjukkan persentase sangat tinggi sebesar 87,90\%. Berdasarkan analisis hasil observasi dan respon mahasiswa terkait keaktifan mahasiswa dalam pembelajaran daring menggunakan model FL, menunjukkan adanya ruang yang diberikan kepada mahasiswa untuk lebih aktif dalam pembelajaran ini. Keaktifan mahasiswa dalam pembelajaran ini lebih ditunjukkan pada keaktifan kumulatif atau merata, dan bukan dominasi sebagian dari mahasiswa. Ini berarti, interaksi dalam pembelajaran daring menggunakan model FL antara guru/dosen dengan mahasiswa bersifat luas. Dampak interaksi 


\section{Jurnal Inovasi Pendidikan IPA, 7 (1), 2021 - 30}

Abdul Rasid Saraha, Sudir Umar, Nurfatimah Sugrah

antara guru/dosen dengan mahasiswa yang lebih merata dapat meningkatkan motivasi belajar mahasiswa secara akumulatif. Hal ini juga ditunjukkan pada respon motivasi belajar mahasiswa dalam pembelajaran daring menggunakan model FL.

Motivasi belajar mahasiswa dalam pembelajaran daring ini dianalisis dari sejumlah pertanyaan terkait dorongan mahasiswa untuk mencari, melakukan literasi digital, serta berdiskusi dalam menemukan jawaban pertanyaan. Pengukuran motivasi belajar mahasiswa disajikan pada Gambar 4 diagram motivasi belajar mahasiswa. Berdasarkan respon angket mahasiswa, pembelajaran daring menggunakan model FL menunjukkan kemampuan memberikan motivasi yang kuat (90\%) kepada mahasiswa dalam mencari tahu jawaban dan melakukan literasi digital untuk menjawab ataupun berargumentasi dalam pembahasan materi pembelajaran. Ini berarti pemberian materi yang disajikan dalam bentuk ilustrasi yang disisipkan keyword sebagai kata bantu dalam pembelajaran mahasiswa, teridentifikasi mampu memberikan stimulus positif kepada mahasiswa dengan menggugah rasa ingin tahu yang besar. Rasa ingi tahu yang kuat, selanjutnya ditindak lanjuti oleh sebagian besar mahasiswa untuk mencari jawaban dengan cara diskusi dan penelusuran sumber pustaka melalui aktivitas literasi. Dibandingkan motivasi untuk melakukan literasi, dorongan untuk diskusi menunjukkan sedikit lebih rendah $(83,30 \%)$. Pada pembelajaran daring menggunakan model FL, aktivitas literasi sangat didorong untuk dilakukan oleh para mahasiswa.

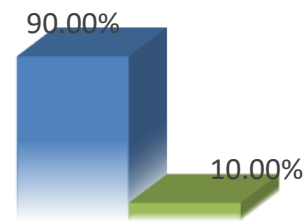

(a)

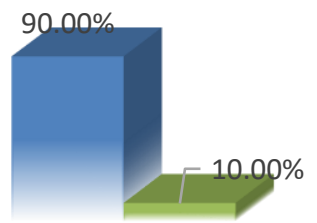

(b)

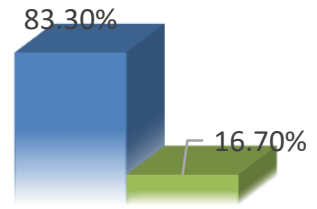

(c)

- termotivasi tidak termotivasi

Gambar 4. Diagram motivasi mahasiswa

(a) Dorongan untuk mencari tahu jawaban, (b) Dorongan melakukan literasi digital, (c) Dorongan untuk berdiskusi.

Aktivitas literasi mahasiswa dalam pembelajaran daring dianalisis lebih lanjut dengan mencari respon tanggapan mahasiswa tentang penggunaan mesin pencarian untuk literasi digital, selektivitas mahasiswa terhadap sumber pustaka dalam aktivitas literasi digital serta melihat kecenderungan mahasiswa untuk melakukan literasi dibandingkan dengan diskusi pada pembelajaran daring (Gambar 5). Respon tanggapan mahasiswa menunjukkan bahwa, hampir semua mahasiswa $(96,40 \%)$ memilih menggunakan mesin pencarian untuk menelusuri pustaka atau sumber referensi dalam pembelajaran daring. Hal ini dapat dipahami karena pembelajaran daring lebih mendekatkan pada lingkungan digital yang dapat memberikan akses literasi yang sangat luas dengan hanya memasukkan kata kunci pencarian pada mesin pencarian.

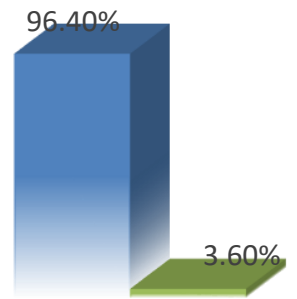

(a)

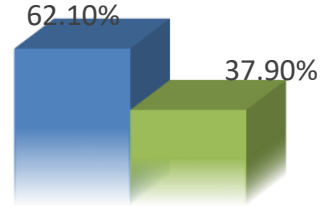

(b)

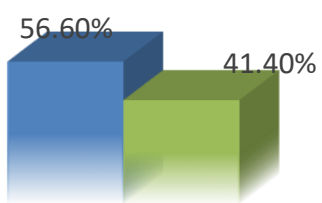

(c)

Gambar 5. Diagram aktivitas literasi mahasiswa

(a) Mahasiswa melakukan penelusuran dengan mesin pencarian, (b) Mahasiswa melakukan seleksi pustaka hasil pencarian, (c) Mahasiswa melakukan literasi digital dibandingkan diskusi dengan teman. 


\section{Jurnal Inovasi Pendidikan IPA, 7 (1), 2021 - 31}

Abdul Rasid Saraha, Sudir Umar, Nurfatimah Sugrah

Sedangkan dalam proses pembelajaran daring menggunakan model FL ini, dibandingkan berdiskusi dengan teman, mahsiswa lebih memilih melakukan literasi mandiri dengan menggunakan mesin pencarian. Hal ini senada dengan respon motivasi mahasiswa yang lebih terdorong melakukan literasi digital. Namun masalah lain dalam penggunaan mesin pencarian sebagai sumber utama penelusuran pustaka adalah minimnya selektifitas mahasiwa terhadap kualitas pustaka rujukan yang digunakan. Hal ini tercermin dalam respon tanggapan mahasiswa yang menunjukkan bahwa lebih dari $37 \%$ mahasiswa tidak melakukan penyaringan/pemilahan sumber referensi yang digunakan untuk membangun argumentasi. Kemampuan mahasiswa dalam mengenali sumber literatur seperti artikel lepas, jurnal penelitian maupun buku elektronik dilaporkan sebesar 55,20\% yang mampu membedakan, sedangkan $44,80 \%$ lainnya tidak mengenali sumber pustaka yang digunakan.

Pembelajaran daring dengan model FL, merupakan proses pembelajaran yang di dalamnya tidak dapat dipisahkan dengan akivitas literasi untuk membangun argumentasi dalam diskusi pembelajaran. Dalam pembelajaran ini, mahasiswa didorong untuk melakukan aktivitas literasi untuk meningkatkan kemampuan berpikir kritis. Indikator ketercapaian keterampilan berpikir kritis mahasiswa dapat ditinjau dari kualitas argumentasi yang disajikan dalam pembelajaran tersebut. Proses penyajian argumentasi mahasiswa dalam pembelajaran ini dipetakan dalam 3 skema, yakni penelusuran, studi pustaka dan mengemukakan argumentasi (Gambar 1). Aktivitas berargumentasi merupakan bagian dari keterampilan berpikir kritis (Halpern, 1998), yang dicirikan oleh kemampuan mengidentifikasi ambiguitas dalam sebuah argument (Lai, 2011). Berdasarkan hasil observasi, dari 60,54\% (Tabel 2) mahasiwa telah mampu menyajikan argumentasi yang bebas praktik plagiat. Ini menunjukkan kemampuan mahasiswa dalam menggunakan keterampilan berpikir kritis untuk mengelola informasi dan menyajikannya dalam bentuk argumentasi.

\section{Tanggapan Pembelajaran Daring}

Pembelajaran daring menggunakan model FL memiliki beberapa keunggulan dan kekurangan dalam proses pembelajarannya, beberapa diantaranya menurut pendapat mahasiswa terkait karakteristik, keefektifan dan peningkatan minat belajar (Gambar 6). Tidak semua mahasiswa merasa nyaman dengan pembelajaran daring, karena karakteristik belajar mahasiswa yang beragam memberikan pengaruh yang besar terhadap pola pembelajaran mahasiswa (Kintu \& Zhu, 2016). Sedangkan efektivitas pembelajaran menggunakan model dan metode pembelajaran dapat dipengaruhi gaya belajar mahasiswa (Dantas \& Cunha, 2020).

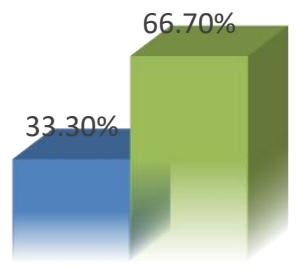

(a)

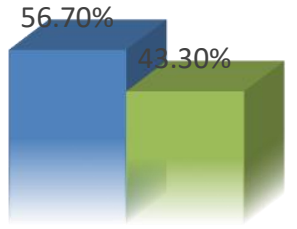

(b)

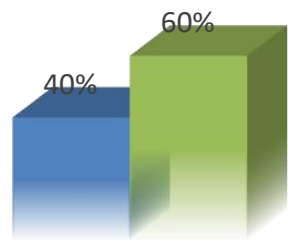

(c)

$$
\text { m Ya }=\text { Tidak }
$$

Gambar 6. Diagram pendapat mahasiswa

(a) Pembelajaran membosankan, (b) pembelajaran lebih efektif, dan (c) pembelajaran meningkatkan minat belajar.

Lebih dari sepertiga mahasiswa yang mengikuti pembelajaran daring dengan FL, menyatakan bosan dengan pembelajaran yang dilakukan. Hal ini disinyalir karena sebagian aktivitas mahasiswa yang menunggu komentar ataupun argumentasi temannya dalam kolom komentar. Secara visual dan audio pembelajaran daring menggunakan aplikasi ini, juga tidak memberikan suasana maupun lingkungan yang lebih bervasiasi. Dengan durasi pembelajaran lebih dari 1 jam dalam kondisi lingkungan pembelajaran seperti tergambar diatas, maka efek bosan merupakan tantangan utama dalam pembelajaran ini.

Disamping kondisi bosan, sebagian mahasiswa juga berpendapat bahwa pembelajaran ini tidak meningkatkan minat belajar mahasiswa dan kurang efektif. Respon tanggapan ini menunjukkan bahwa proses pembelajaran tidak terlalu diinginkan kembali oleh sebagian mahasiswa, dengan indikasi pendapat mahasiswa yang menyatakan pembelajaran ini kurang meningkatkan minat belajar. Namun untuk 


\section{Jurnal Inovasi Pendidikan IPA, 7 (1), 2021 - 32}

Abdul Rasid Saraha, Sudir Umar, Nurfatimah Sugrah

efektivitas pembelajaran, data hasil belajar mahasiswa menunjukkan peningkatan dengan pembelajaran ini. Pembelajaran daring dengan FL, memberikan ruang pengelolaan dan interaksi kelas yang lebih mudah serta merata dengan bantuan aplikasi pembelajaran. Hal ini berdampak pada keaktifan mahasiswa yang lebih banyak atau merata dalam kelas, namun mungkin sedikit mengabaikan dominasi sebagian mahasiswa yang memiliki potensi lebih aktif untuk berkembang lebih cepat.

\section{SIMPULAN}

Penerapan pembelajaran daring menggunakan model forensik literasi (FL) dalam pembahasan materi kinetika reaksi mata kuliah kimia dasar untuk mahasiswa, terbukti dapat meningkatkan hasil belajar mahasiswa meskipun pembelajaran dilakukan pada kondisi tanpa tatap muka di kelas. Disamping mampu meningkatkan hasil belajar mahasiswa, pembelajaran ini juga dapat meningkatkan motivasi belajar mahasiswa khususnya dalam melakukan aktivitas literasi digital. Dalam pembelajaran ini, ketersediaan sumber daya baik berupa perangkat instrumen maupun sumber daya manusia untuk mengoperasikan aplikasi pembelajaran daring sangat dibutuhkan untuk proses kelancaran pembelajaran ini. Efektivitas pembelajaran daring dengan menggunakan model FL, dapat terus ditingkatkan dengan melakukan inovasi dan pengembangan pada bagian konten serta kemasan pembelajaran untuk mendapatkan pembelajaran yang lebih menarik dan mampu meningkatkan minat belajar mahasiswa. Penerapan pembelajaran interaktif dengan menggunakan model ini jugaperlu dikaji untuk mendapatkan pembelajaran yang lebih efektif.

\section{DAFTAR PUSTAKA}

Abidin, Z., \& Jupri, A. (2017). The use of multiliteration model to improve mathematical connection ability of primary school on geometry. IJAEDU-International E-Journal of Advances in Education, 3(9), 603-610.

Aliyu, F., \& Talib, C. A. (2019). Virtual chemistry laboratory: A panacea to problems of conducting chemistry practical at science secondary schools in Nigeria. International Journal of Engineering and Advanced Technology, 8(5), 544-549. https://doi.org/10.35940/ijeat.E1079.0585C19

Badriyah, N. L., Anekawati, A., \& Azizah, L. F. (2020). Application of PjBL with brain-based STEAM approach to improve learning achievement of students. Jurnal Inovasi Pendidikan IPA, 6(1), 88-100. https://doi.org/10.21831/jipi.v6i1.29884

Boling, E. C., Hough, M., Krinsky, H., Saleem, H., \& Stevens, M. (2012). Cutting the distance in distance education: Perspectives on what promotes positive, online learning experiences. Internet and Higher Education, 15(2), 118-126. https://doi.org/10.1016/j.iheduc.2011.11.006

Chanprasitchai, O. A., \& Khlaisang, J. (2016). Inquiry-based learing for a virtual learning community to enhance problem-solving ability of applied thai traditional medicine students. Turkish Online Journal of Educational Technology, 15(4), 77-87.

Cheung, C., \& Cable, J. (2017). Eight principles of effective online teaching: A decade-long lessons learned in project management education. PM World Journal Eight Principles of Effective Online Teaching, VI(7), 1-16. http://pmworldjournal.net/article/eight-principles-effectiveonline-teaching/

Dantas, L. A., \& Cunha, A. (2020). An integrative debate on learning styles and the learning process. Social Sciences \& Humanities Open, 2(1), 100017. https://doi.org/10.1016/j.ssaho.2020.100017

Gorbunovs, A., Kapenieks, A., \& Cakula, S. (2016). Self-discipline as a Key Indicator to Improve Learning Outcomes in e-learning Environment. Procedia - Social and Behavioral Sciences, 231(May), 256-262. https://doi.org/10.1016/j.sbspro.2016.09.100

Halpern, D. F. (1998). Teaching critical thinking for transfer across domains: Disposition, skills, structure training, and metacognitive monitoring. American Psychologist, 53(4), 449-455. https://doi.org/10.1037/0003-066X.53.4.449

Jeong, H., \& Hmelo-Silver, C. E. (2010). Productive use of learning resources in an online problembased learning environment. Computers in Human Behavior, 26(1), 84-99.

https://doi.org/10.1016/j.chb.2009.08.001 


\section{Jurnal Inovasi Pendidikan IPA, 7 (1), 2021 - 33}

Abdul Rasid Saraha, Sudir Umar, Nurfatimah Sugrah

Kintu, M. J., \& Zhu, C. (2016). Student characteristics and learning outcomes in a blended learning environment intervention in a Ugandan university. Electronic Journal of E-Learning, 14(3), 181-195.

Lee, S. J., Srinivasan, S., Trail, T., Lewis, D., \& Lopez, S. (2011). Examining the relationship among student perception of support, course satisfaction, and learning outcomes in online learning. Internet and Higher Education, 14(3), 158-163. https://doi.org/10.1016/j.iheduc.2011.04.001

Meiyanti, R., \& Ismaniah, I. (2015). Perkembangan digital forensik saat ini dan mendatang. Jurnal Karya Ilmiah, 15(2).

Mirazita, Y., \& Rohmiyati, Y. (2015). Studi literasi informasi mahasiswa ko-asisten Fakultas Kedokteran Universitas Diponegoro menggunakan the empowering eight model. Jurnal Ilmu Perpustakaan, 4(2), 78-85. https://ejournal3.undip.ac.id/index.php/jip/article/view/9509

Moore, J. L., Dickson-Deane, C., \& Galyen, K. (2011). E-Learning, online learning, and distance learning environments: Are they the same? The Internet and Higher Education, 14(2), 129-135. https://doi.org/10.1016/j.iheduc.2010.10.001

Oktavian, R., \& Aldya, R. F. (2020). Efektivitas pembelajaran daring terintegrasi di era pendidikan 4.0. Didaktis: Jurnal Pendidikan Dan Ilmu Pengetahuan, 20(2), 129-135. https://doi.org/10.30651/didaktis.v20i2.4763

Oludare Jethro, O., Moradeke Grace, A., \& Kolawole Thomas, A. (2012). E-Learning and Its Effects on Teaching and Learning in a Global Age. International Journal of Academic Research in Business and Social Sciences, 2(1), 2222-6990.

Picciano, A. G. (2017). Theories and frameworks for online education: Seeking an integrated model. Online Learning Journal, 21(3), 166-190. https://doi.org/10.24059/olj.v21i3.1225

Rakhman, K. A., Saraha, A. R., \& Sugrah, N. (2018). Basic competency of chemical practicum: Development and validation of assessment instruments. International Conference On Teaching and Learning, 1 .

Setiaji, B., \& Dinata, P. A. C. (2020). Analisis kesiapan mahasiswa jurusan pendidikan fisika menggunakan e-learning dalam situasi pandemi Covid-19. Jurnal Inovasi Pendidikan IPA, 6(1), 59-70. https://doi.org/10.21831/jipi.v6i1.31562

Setiawan, R., Mardapi, D., Pratama, A., \& Ramadan, S. (2019). Efektivitas blended learning dalam inovasi pendidikan era industri 4.0 pada mata kuliah teori tes klasik. Jurnal Inovasi Teknologi Pendidikan. https://doi.org/10.21831/jitp.v6i2.27259

Syah, R. H. (2020). Dampak Covid-19 pada pendidikan di Indonesia: Sekolah, keterampilan, dan proses pembelajaran. SALAM: Jurnal Sosial Dan Budaya Syar-I, 7(5). https://doi.org/10.15408/sjsbs.v7i5.15314

Tatli, Z., \& Ayas, A. (2010). Virtual laboratory applications in chemistry education. Procedia - Social and Behavioral Sciences, 9, 938-942. https://doi.org/10.1016/j.sbspro.2010.12.263

Tatli, Z., \& Ayas, A. (2013). Effect of a virtual chemistry laboratory on students' achievement. Educational Technology \& Society, 16(1), 159-170. http://www.ifets.info/journals/16_1/14.pdf

Yen, S. C., Lo, Y., Lee, A., \& Enriquez, J. M. (2018). Learning online, offline, and in-between: comparing student academic outcomes and course satisfaction in face-to-face, online, and blended teaching modalities. Education and Information Technologies, 23(5), 2141-2153. https://doi.org/10.1007/s10639-018-9707-5

Zheng, B., Lin, C., \& Bae, J. (2020). Computers \& Education The impact of learner- , instructor- , and course-level factors on online learning. Computers \& Education, 150(January), 103851. https://doi.org/10.1016/j.compedu.2020.103851 